\title{
Regulatory acts for the cultural patrimony preservation of Porto Murtinho, Mato Grosso do Sul, in university context of the Network of the Latin American Integration Route (UniRila) and the Bioceanic Corridor
}

\author{
Atos normativos para preservação do patrimônio cultural de Porto Murtinho, \\ Mato Grosso do Sul, no contexto da Rede Universitária da Rota de Integração \\ Latino-Americana (UniRila) e o Corredor Bioceânico
}

\section{Actos normativos para preservación del patrimonio cultural de Porto Murtinho, Mato Grosso do Sul, en el contexto de la Red Universitaria de la Ruta de Integración Latinoamericana (UniRila) y el Corredor Bioceánico}

\author{
Mariana de Barros Casagranda Akamine ${ }^{1}$ \\ Érika Santos Silva ${ }^{1}$ \\ Maria Margareth Escobar Ribas Lima² \\ Rodrigo Mendes de Souza ${ }^{3}$
}

Received on $1^{\text {st }}$ July 2021; revised and approved on 17 Sept. 2021; accepted on 13 Oct. 2021

DOI: hhttp://dx.doi.org/10.20435/inter.v22i4.3431

\begin{abstract}
This work is part of the activities that were agreed within the scope of the University Network of the Latin American Route (UniRila), and was developed specifically as a proposal for Dossier II. This research is also linked to the development of the Master Plan of Porto Murtinho, Mato Grosso do Sul (MS), specifically the axis of Cultural Historical Heritage, the result of an inter-institutional partnership. In this context, the aim is to analyze current normative acts for the preservation of historical and cultural heritage in the three administrative spheres, using the qualitative approach methodology with bibliographic and documentary research. One of the great challenges of the Bioceanic Route Integration will be the efficient updating of policies for the preservation of the historical and cultural heritage, in order to maintain the cultural integrity of the local population. Thus, it is understood the need to stimulate local development, through cultural and social capital, aiming at a participatory democracy. Heritage education is part of this context as an instrument for disseminating information and knowledge, and when supported by public and private agents and social actors, they are certainly decisive in the struggle arising from issues related to cultural vulnerability.

Keywords: Bioceanic Route; normative acts; UniRila; historic heritage; Porto Murtinho, MS.

Resumo: Este trabalho insere-se nas atividades que foram acordadas no âmbito da Rede Universitária da Rota Latino-americana (UniRila), e foi desenvolvido especificamente como proposta para o Dossiê II. A presente pesquisa está atrelada também ao desenvolvimento do Plano Diretor de Porto Murtinho, Mato Grosso do Sul (MS), especificamente ao eixo do Patrimônio Histórico Cultural, fruto de parceria interinstitucional. Neste contexto, visa-se analisar atos normativos vigentes para a preservação do patrimônio histórico e cultural nas três esferas administrativas, utilizando da metodologia de abordagem qualitativa com pesquisa bibliográfica e documental. Um dos grandes desafios da Integração da Rota Bioceânica será a atualização eficiente das políticas de preservação do patrimônio histórico e cultural, de forma a manter a integridade cultural da população local. Assim, compreende-se a necessidade de estímulo ao desenvolvimento local, por meio do capital cultural e social, objetivando uma democracia participativa. A educação patrimonial insere-se nesse contexto, como instrumento de disseminação de informação e conhecimento e quando apoiada por agentes públicos, privados e atores sociais, é certamente, decisiva na luta decorrente das questões relativas à vulnerabilidade cultural.
\end{abstract}

Palavras-chave: Rota Bioceânica; atos normativos; UniRila; patrimônio histórico; Porto Murtinho, MS.

Resumen: Este trabajo forma parte de las actividades que se acordaron en el ámbito de la Red Universitaria de la Ruta Latinoamericana (UniRila), y se desarrolló específicamente como propuesta para el Dossier II. Esta investigación también está vinculada al desarrollo del Plan Director de Porto Murtinho, Mato Grosso do Sul

\footnotetext{
${ }^{1}$ Universidade Católica Dom Bosco (UCDB), Campo Grande, Mato Grosso do Sul, Brasil.

2 Instituto do Patrimônio Histórico e Artístico Nacional (IPHAN), Campo Grande, Mato Grosso do Sul, Brasil.

${ }^{3}$ Universidade Federal de Mato Grosso do Sul (UFMS), Campo Grande, Mato Grosso do Sul, Brasil.
} 
(MS), específicamente el eje de Patrimonio Histórico Cultural, resultado de una alianza interinstitucional. En este contexto, el objetivo es analizar los actos normativos vigentes para la preservación del patrimonio histórico y cultural en los tres ámbitos administrativos, utilizando la metodología de enfoque cualitativo con investigación bibliográfica y documental. Uno de los grandes desafíos de la Integración de la Ruta Bioceánica será la actualización eficiente de las políticas de preservación del patrimonio histórico y cultural, a fin de mantener la integridad cultural de la población local. Así, se entiende la necesidad de estimular el desarrollo local, a través del capital social y cultural, buscando una democracia participativa. La educación patrimonial forma parte de este contexto como instrumento de difusión de información y conocimiento, y cuando es apoyada por agentes públicos, privados y actores sociales, sin duda es decisiva en la lucha que surge de los temas relacionados con la vulnerabilidad cultural.

Palavras-chave: Ruta Bioceánica; actos normativos; UniRila; patrimonio histórico; Porto Murtinho, MS.

\section{INTRODUCTION}

The present work emerged through activities agreed within the scope of the University Network of the Latin American Route (UniRila), which includes the following universities: 1. BRAZIL (Universidade Católica Dom Bosco [UCDB]), Universidade Estadual de Mato Grosso do Sul [UEMS], Universidade Federal de Mato Grosso do Sul [UFMS], Universidade Anhaguera-Uniderp, Instituto Federal de Mato Grosso do Sul [IFMS]); 2. PARAGUAY (Universidad Autonôma de Asunción [UAA]); 3. ARGENTINA (Universidad Nacional de Salta [UNSA], Universidad Nacional de Jujuy [UNJu]); and 4. CHILE (Universidad Católica del Norte de Chile [UCN], Universidad de Antofagasta [UANTOF]). The University Network aims to carry out research and extension work to better understand local realities and identify situations of vulnerability and risk, with the ultimate objective of proposing the development of coping strategies for the problems raised, in order to improve the living conditions of the populations of territories that are part of the Bioceanic Highway Corridor.

This research is part of the ongoing studies "Support to the development of the Master Plan of Porto Murtinho, Mato Grosso do Sul-MS" as a result of an interinstitutional partnership, with an interdisciplinary vision, between the municipality and universities of Mato Grosso do Sul (UFMS, UCDB, UEMS), from its researchers, collaborating in the elaboration of the Master Plan with a view to the development of the municipality.

During the period 2020 and 2021, the group of researchers traveled to the city of Porto Murtinho, MS, to prepare some surveys on the city's historical and cultural heritage. Thus, it was observed that the existing normative acts will not meet the demand for adequate heritage preservation to accommodate the flow of people that the Bioceanic Corridor will develop in the city, resulting in the need for revision and inclusion of new preservation and listing laws. It was also found that in recent years new forms of local tourism have developed.

In this context, this project intends to focus on the perspectives of cultural public policies in the three administrative spheres, highlighting in Porto Murtinho, MS, the existing cultural, social and educational projects. Thus, the objective is to minimize, through preventive actions, through music, theater, cultural activities in general, the issues that permeate the field of social vulnerability, development and sustainability of the populations that make up the municipality's territory.

\section{BIOCEANIC CORRIDOR}

The creation of the Bioceanic Highway Corridor was intended to promote an important road connection between the Brazilian Midwest and the Pacific Ocean, thus allowing the flow of production and the direct import of inputs, and making their economic value more attractive. 
The flow of the Bioceanic Integration Route will take place through the connection of the four agreed countries: Brazil, Paraguay, Argentina and Chile, aiming at reducing the time for cargo displacement, improving logistics and promoting the competitiveness of exports to Asia. In this context, it is possible to foment the promotion of tourism and new regional trade flows.

The Bioceanic Route will start in the city of Porto Murtinho, MS (Brazil); it will cross Paraguayan territory through Carmelo Peralta, Mariscal Estigarribia and Pozo Hondo (Paraguay); on Argentine territory in the cities of Misión La Paz, Tartagal, Jujuy and Salta (Argentina); finally in Chilean territory, through the Pass of Jama, until reaching the ports of Antofagasta, Mejillones and Iquique.

The city of Porto Murtinho is located in the west of the state of Mato Grosso do Sul, on the banks of the Paraguay River in the middle of the Pantanal, and has a population of 15,372 people (IBGE, 2010).

It was in a perspective view of development arising from the departure of erva-mate through the port, that the municipality emerged. The idea of transporting the mate herb through the port came after Thomáz Laranjeira joined as civil secretary in the Mixed Limits Commission, to demarcate the dividing lines between Brazil and Paraguay. The invitation came from the engineer colonel Rufino Eneas Gustavo Galvão, Viscount of Maracajú, who fought in the Paraguay war and, after its end, remained in Porto Murtinho commanding the commission.

The history of Porto Murtinho began at the end of the 19th century, when a river port was created, with the aim of transporting the production of yerba mate. The choice of the site $50 \mathrm{~km}$ upstream of the Apa River, on the Paraguay River, was mainly due to the ease of access due to the lesser proximity of the non-swampy area to the left bank of the Paraguay River. The city is limited to the north by Corumbá, to the south and west by the Republic of Paraguay, to the east by Bonito, Jardim and Bodoquena. (LIMA, 2013, p. 79).

In the early days, Porto Murtinho's economy was heated through livestock production, trade in turn was commanded by the port agency of Porto Murtinho Ltda. Fishing tourism was already present at the time, also presenting a considerable flow of people. The first economic cycle dealt with in the region was the erva mate cycle negotiated between Thomaz Larangeira and the natives, who were responsible for harvesting and producing the herb in their barbacuás (LIMA, 2013). Porto Murtinho maintains a distance of 400 kilometers from the state capital, Campo Grande, and as it is not a place of passage, having sporadic accesses, it managed to preserve the vast majority of its buildings built in the late 19th and early 20th centuries. The set of these buildings provides a beautiful perspective on the history inherited and reflected in the built historical heritage.

\section{THE CULTURAL HERITAGE OF PORTO MURTINHO, MS}

Braz and Oliveira (2013, p. 108) claim that "[...] the territory is at the same time a social and cultural space, since: while one is produced, the other is experienced". The space is then heterogeneous, as the geographic model itself is defined by the circulation which, as it is more numerous, holds the command of changes in value in space (SANTOS, 2006). The concept of local development for Ávila (2000) also results from cultural dynamism, which enables the local community to expand its capacity to direct and transform the types of support coming from abroad.

The creation of Porto Murtinho, MS took place in 1911 and its emancipation on June 13, 1912. Over 100 years the city was the stage of important historical events such as: War of the 
Triple Alliance, Revolution of 1932. Porto Murtinho also presents a exuberant scenery, represented by the magnificence and beauty of the Paraguay River.

The border with Paraguay and its strategic proximity to important tourist cities such as Bonito, Jardim and the Bodoquena National Park, the Pantanal de Nabileque and five indigenous villages, make Porto Murtinho a potential for cultural, tourist and also business productivity.

As it is also a secular city, it has historical buildings and monuments that make up the cultural heritage of the state of Mato Grosso do Sul. By adding some of the uses and customs of the neighboring country Paraguay, focused on music, dance, theater and other attractions, culture of the municipality is remarkable, valuing and extolling the traditions of the Murtinian population.

The culture as a community product is guided by principles and values that support the cultural paradigm of a people: whether in the orientation to their customs, habits, folklore, way of living and doing, represented by art in its different expressions and by the way of diffusion and preservation.

\section{POLICIES FOR THE PRESERVATION OF CULTURAL HERITAGE}

The meaning of the word "Heritage" is related to ancient family structures, and derives from the Latin "pater". Currently, the idea of family inheritance, belonging to someone or a group, is still linked (VILLELA, 2017).

To understand the nuances surrounding patrimony, a brief approach to the main concepts are very necessary.

Candau (2012) states that memory is essentially linked to memories or recognitions. Since ancient times, men felt the need to externalize their memories, through the production of traces, with the aim of transmitting these signals.

For the author, collective memories are intimately linked to the representations that members of a group produce regarding events linked to its participants, which ends up being related to the field of local identity. Thus, Candau (2012, p. 50) highlights that "[...] the collective memory, as the identity of which it is the fuel, does not exist but differentially, in an ever-changing relationship maintained with the other".

For Villela (2017), the term "patrimony" appears in literature linked to the first conservationist theories of the 19th century, after the French Revolution and the Industrial Revolution in England, directed to the restoration of monuments and historic buildings, with the purpose of protection and preservation.

Among some preservationist theories that date back to this period, the one of Eugène Viollet-Le-Duc (1814-1879), in France, in charge of the Commission on Historical Monuments in the city of Paris, stands out. Viollet-Le-Duc, presents itself in a period known as stylistic restoration, in which it defended an interventionist and medievalist doctrine, when the present prevailed over the past and the aesthetic value over the historical (UNES; CAVALCANTE, 2008).

In England, John Ruskin (1819-1900) stood out prominence with the so-called romantic restoration, with the archaeologist thesis, an anti-interventionist doctrine, when the past prevailed over the present and historical value prevailed over the aesthetic (UNES; CAVALCANTE, 2008). $\mathrm{He}$ also defended that the population of a specific location would be the heir of these cultural assets, establishing a relationship of belonging and commitment, between the present and future generations, for the preservation of historic buildings in their original conception. 
Several other preservationist theories were presented during this period, such as Camillo Sitte and Alois Riegl, in Austria, and Cesare Brandi, also in Italy, among others. Such preservation actions were being adopted to safeguard the historical heritage, aiming at the protection of buildings, considered important for society.

The problem of conservation and restoration was amplified throughout the 20th century, not only due to the efforts of theorists and critics such as Camillo Boito, Alois Riegl and Cesare Brandi, but also to an important event that consolidated the principles and doctrines concerning preservation heritage, the 1st International Congress of Architects and Technicians of Historical Monuments, organized in Athens, in 1931, by the International Office of Museums of the Society of Nations. (VILLELA, 2017, p. 47).

The document that emerged from the 1st International Congress of Architects and Technicians of Historical Monuments, was a landmark, and served as a basis for the reformulation of legislation regarding the preservation of heritage, throughout the world, opening paths for a series of other documents that would come next, known as Patrimonial Letters. The Patrimonial Letters are not framed as laws or regulations, they are documents that cover and synthesize the points of consensus that permeate the heritage, and must be analyzed within a historical, cultural and temporal context.

Heritage issues, from 1945, when the United Nations Educational, Scientific and Cultural Organization (UNESCO) was founded, began to be protected worldwide, when in 1959, the first international campaigns took place.

In Brazil, UNESCO has been active since 1977, through the implementation of the World Heritage Convention, collaborating with governments in the three spheres and also in conjunction with civil society.

Currently, the Brazilian policy for the preservation of historical heritage is responsible for the Institute of National Historical and Artistic Heritage (IPHAN), linked to the Ministry of Culture, which, in addition to safeguarding the heritage, also discloses preservation methodologies and criteria for the entire country.

\subsection{Federal level}

The national policy of cultural preservation patrimony is based on the Federal Constitution of 1934, in which Articles 10 and 148 define the competence to protect the Historic Heritage.

Subsequently, Decree-Law n. 25 of November 30, (BRASIL, 1937) defined the three levels of the hierarchy of heritage preservation with their respective managers: national, state and municipal levels; as well, it established the importance of community participation.

The regulation in question, organizes the protection of the national historical and artistic heritage, and defines in its Article 1:

The national historical and artistic heritage is the set of movable and immovable property existing in the country and whose conservation is of public interest, either because of its link to memorable facts in the history of Brazil, or because of its exceptional archaeological or ethnographic, bibliographical or artistic value. (BRASIL, 1937).

Based on legal regulations, in the three administrative spheres, it is understood that a cultural asset can be material, immaterial or interconnected between them, as well as being relevant in terms of memory in more than one territorial level, and that instruments of simultaneous 
protection, such as being listed at the municipal and state level, or at the state and federal level, or at the municipal and federal level, or even at all levels.

The Federal Constitution of 1937 (BRASIL, 1937) enshrines the protection of the national cultural patrimony, since from then on, it was possible to create legal instruments, such as DecreeLaw No. 25/37, which aimed to safeguard assets of remarkable historical and art value of the country.

A little more than twenty years after the 1937 Constitution, Law n. 3.924 (BRASIL, 1961), was published, which specifically deals with policies relating to archaeological and prehistoric monuments, establishing that they should be under custody and protection of the Public Power.

For Porta (2012), in view of the need to update and expand the concepts brought by the Federal Constitution of 1937, so that the historical and cultural legacies of the Brazilian trajectory were encompassed in its entirety, the Federal Constitution of 1988 emerges, modernizing, highlighting heritage issues in Brazil and updating its preservation policy.

In his text, the 1988 Federal Constitution, provides in Articles 215 and 216 settings for safeguarding the cultural brasilian patrimony:

Art. 215. The State will guarantee to everyone the full exercise of cultural rights and access to the sources of national culture, and will support and encourage the appreciation and dissemination of cultural manifestations.

$\S 1$ The State will protect the manifestations of popular, indigenous and Afro-Brazilian cultures, and those of other groups participating in the national civilizing process.

$\S 2$ The law will provide for the setting of highly significant commemorative dates for different national ethnic segments. (BRASIL, 1988).

Art. 216 expands the definition previously described in Decree-Law n. 35, of November 30 (BRASIL, 1937), changing the name of Historical and Artistic Heritage by Brazilian Cultural Heritage.

Art. 216. The material and immaterial assets of Brazilian cultural heritage, taken individually or together, bearer of reference to the identity, action, memory of the different groups that make up Brazilian society, including:

I- the forms of expression;

II- ways of creating, doing and living;

III- scientific, artistic and technological creations;

IV- works, objects, documents, buildings and other spaces intended for artistic and cultural manifestations;

V- urban sets and sites of historical, scenic, artistic, archaeological, paleontological, ecological and scientific value. (BRASIL, 1988).

Even before the inclusion of Constitutional Amendment n. 48, 2005, which established the National Cultural Plan, aimed at the country's cultural development, Decree n. 3.551 was published (BRASIL, 2000).

The decree in question institutes the registration of goods of an immaterial nature which, according to Article 1, paragraph 2, are "[...] references to the historical continuity of the property and its national relevance for Brazilian memory, identity and social formation" (BRASIL, 2000), or that is, in general goods more linked to Brazilian popular culture and tradition. It institutes the registration of these assets in the Registration Books, attributing to them the title of "Brazilian Cultural Heritage", title to be reassessed at least every 10 years so that it is maintained.

The evolution, even if slow, of issues related to legal regulations that permeate the field of the patrimony preservation is notorious. Mainly, after the 2000s, and the publication of Decree n. 3.551 (BRASIL, 2000), which ended up establishing the registration of cultural assets of an 
immaterial nature, starting the first inventory and registration actions in 2002, which effectively, advances in preservation policies.

The first landmarks stand out about registrations of remnant areas of quilombos, in 2002, the National Program of Intangible Patrimony launch, in 2004, the beginning of the program Legados da Imigração, in 2007, which resulted in goods related to German and Italian immigration, Ukrainian and Polish, inventoried in Santa Catarina. Porta (2012) also mentions the listing of the Casa de Chico Mendes, in 2008, Ordinance n. 127 of 2009 creating the Cultural Landscape seal, the first listing relating to indigenous culture, in the sacred places of the Xingu people in 2010 and also in this year, the first national naval heritage landmarks, protecting 4 traditional vessels and the collection of the Museu Nacional do Mar (PORTA, 2012).

It is worth mentioning Ordinance n. 420, of December 22, 2010, "[...] which provides for the procedures to be observed for the granting of authorization to carry out interventions in listed buildings and in the respective surrounding areas" (IPHAN, 2010, s.p.), aiming at prevention in a manner that it is possible to preserve the integrity of the property, the planning of the work to be developed, the proportionality of requirements with the level of complexity of the works or interventions to be carried out, inspection and dissemination of information.

The n. 200, of May 18, 2016 ordinance, aims to regulate the National Intangible Heritage Program (PNPI), in order to implement, execute, monitor and evaluate the Intangible Heritage Safeguard Policy, among other objectives. The ordinance in question also establishes the division in relation to cultural assets of an immaterial nature, into three macro-processes: identification, recognition and support and promotion.

These actions at the national level are instruments for the preservation of Brazilian history and culture, respecting the national sociocultural diversity, enriching and dynamizing the strategies of public actors and social agents facing preservation.

\subsection{State level}

At the state level, Mato Grosso do Sul Culture Foundation (FCMS), is responsible for promoting and developing the arts, customs, traditions and heritage of Mato Grosso do Sul, which guides through the guidelines established by the Government of the State in the area of culture.

Created by Law n. 422, of December 6, 1983, the FCMS aims to plan, promote, encourage and carry out activities aimed at both artistic dissemination and heritage, aiming at the cultural development of the State. Its main objective is to close population to the diverse artistic and cultural manifestations of Mato Grosso do Sul and promote the State's cultural market.

FCMS also seeks to stimulate activities and promote related to crafts, as like theater, music, dance, visual arts, performing arts, heritage, manifestations and artistic expressions.

Specifically, in relation to the protection of the historical, artistic and cultural patrimony of the State of Mato Grosso do Sul (2008a), the Law n. 3.522, of May 2008 says that they constitute the historical, artistic, archeological, ethnographic, bibliographical, scenic and cultural heritage of the State of Mato Grosso do Sul the movable, immovable, private or public and immaterial assets existing in its territory, which, due to their exceptional historical, aesthetic or cultural value, require the intervention of the Public Power for their registration, registration, conservation and preservation.

The law lists that the movable and immovable property, private or public, considered patrimony are defined as: works of art, objects, buildings, monuments, libraries, archives, 
documents, architectural ensembles, deposits, archaeological sites, landscapes. As immaterial goods, it considers: forms of expression, ways of creating, doing and living, artistic, linguistic and technological creations.

Law n. 3.522, of May 2008 (MATO GROSSO DO SUL, 2008a) also emphasizes the responsibility of the Cultural Foundation of Mato Grosso do Sul, in exercising the protection and surveillance of the State's property. As well, it establishes that they will only become part of the historical, artistic and cultural heritage of the State of Mato Grosso do Sul, after being registered in the Book of Tombo or Books of Records of the FCMS.

It is worth mentioning that State Decree n. 12.686 of December 30, 2008 (MATO GROSSO DO SUL, 2008b), regulates Law n. 3.522, of May 30, 2008 (MATO GROSSO DO SUL, 2008a), which "Provides for the protection of the Historical, Artistic and Cultural Heritage of Mato Grosso do Sul (2008b)". It also institutes the administrative process for the registration of material assets and registration of intangible assets in the State of Mato Grosso do Sul and also determines the procedural instruction referred to in art. 6 of Law n. 3.522.

Only nine years after the regulation of Law n. 3.522, Law n. 5.035, of July 31, 2017, is published, amending Law n. 3.522, of May 30, 2008, which provides for the protection of Historical and Artistic and Cultural Patrimony of Mato Grosso do Sul, with regard to the provisions of Articles 1 and 2. As well as amending the sole paragraph, stating that the Culture Foundation of Mato Grosso do Sul "will carry out the procedural instruction and assembly of the registration or registration process, when by legislative decree and whenever necessary, it will guide the other proponents in the assembly of the registration process or in the registration process".

\subsection{Municipal level}

The municipal planning process relies on the organic laws of the municipalities, which in turn require them to "[...] organize their administration and carry out their activities based on a permanent, decentralized and participatory planning process, as an instrument for the democratization of city management, of structuring the action of the Executive and guiding the action of individuals" (SILVA, 2010, p. 133).

From the determination of the Federal Constitution, in order to ensure municipal autonomy, guarantee the dignity of citizens and the full exercise of their rights, the Organic Law of the Municipality of Porto Murtinho was instituted, in force since April 5, 1990 and updated through several amendments until the year 2018.

In its Article 9 of the Organic Law of the Municipality of Porto Murtinho, the approach to the Municipality's Cultural Heritage begins, where it determines that it is the Municipality's exclusive responsibility to " $\mathrm{X}$ - promote the protection of the local historical and cultural heritage in compliance with the legislation and supervisory action federal and state".

Articles 10, 121, 168, 171 and 185 provide for several other obligations of the municipality regarding the instruments for preserving the historicpatrimony of Porto Murtinho, MS.

Following a chronology regarding the legal frameworks, there is Law n. 1270, of August 29, 2003, which "Institutes the Municipal Council of Culture of Porto Murtinho, MS, and makes other measures", and is intended to assist the Foundation of Culture and Sports of Porto Murtinho (FUNCEPM), in the formulation of the Municipal Culture Policy, as well as monitoring the execution of its plans, programs and projects. 
On April 23, 2009, Municipal Law n. 1403 was created, which "provides for the protection of the Cultural Heritage of the Municipality of Porto Murtinho - State of Mato Grosso do Sul and other measures".

Subsequently, Municipal Law n. 1461 of February 17 (PORTO MURTINHO, 2011a) "[...] reforms the Municipal Council of Culture in the Municipality of Porto Murtinho, MS, and takes other measures".

Also on February 17, 2011, the Municipal Fund for Culture Incentive was created in the Municipality of Porto Murtinho, MS, through Municipal Law n. 1462, of February 17 (PORTO MURTINHO, 2011b), whose objective is to serve as an instrument for implementing the policy. culture, as well as providing support to strictly cultural projects initiated by private individuals or legal entities, in order to stimulate and promote the artistic-cultural production of the Municipality.

\section{SOCIAL VULNERABILITY AND CULTURAL PUBLIC POLICIES}

Social inequality has been a feature present in Brazilian history and a constant concern for researchers and the government. Schumann (2014, p. 30) selected among his studies in the 1980s and 1995, eighteen different types of definitions on the theme of vulnerability. With the intention of demonstrating the multidimensionality of vulnerability, he approached the theme from different perspectives, evidencing the concept expansion until the 21st century.

Social risks are not based on the idea of poverty, but are associated with social aspects related to the term, such as unemployment, difficulty in inclusion, widespread forms of violence, illnesses in social health, and so on.

For Vignoli (2001, p. 2) vulnerability is a reflection of the lack of access to existing social structures and opportunities, which are regularly offered in the market. Busso (2001) analyzes vulnerability as an individual's weakness, reflecting the loss of well-being. The groups and families that intend to take the risks can suffer an impact on their quality of life.

Within the historical context of the vulnerability theme, Cançado, Souza and Cardoso (2014) argue that:

One of the major contributions of the term is the overcoming of simplistic analyzes referring to poverty, because it is a heterogeneous quality, making it necessary to understand it through the intersection of its multi-causal factors. Talking about social risks is not restricted to situations of poverty, but is associated with a wide spectrum of situations, such as unemployment, difficulties in social integration, illnesses, violence, etc. It is, therefore, insufficient to think of merely economic solutions to structural problems, which for the most part have deep roots, such as problems inherited from the national formation itself, deterioration of the democratic system, inefficient urban planning, among others. (CANÇADO; SOUZA; CARDOSO, 2014, p. 2).

The perspective exposed by Cançado, Souza and Cardoso (2014) assume that social vulnerability is not restricted to a certain social class, thus, everyone can be affected by it. But the way this affects society is not always the same; Individuals who depend more frequently on the State as regulator, manager and reducer of the problems faced by the economically poorest population become more vulnerable.

Karl Marx, in his book The Capital, 1867, already observed the contradictions of modern capitalist society, which had the antagonistic character where the basis of its relations and the search for capital profit stood out against the exploitation of the lower working class. In contrast, 
Max Weber did not believe in the possibility of finding reasons for inequality in the economic sphere, as he perceived social class according to the life opportunities shared by similar social actors economically.

Castro (2004) addresses the possibility of finding a mechanism against vulnerability in investing in cultural and symbolic capital. In which the capacity of diverse individuals is expanded so that urban risks disappear. It also bets on the relationship between social capital and state action, resulting in an increase of the economic and social well-being. This would generate a greater participation of society in the formulation, implementation and evaluation of development strategies.

Pointing out the need to deal with vulnerability in an innovative way, Castro (2004) refers to cultural and social capital as stimulating agents of a more participatory democracy focused on the challenges of modernity. In this way, issues associated with negativities should become means of potentializing civilizing changes and positive engagements (CANÇADO; SOUZA; CARDOSO, 2014, p. 16).

Examples of positive vulnerabilities are: society's resistance to consumption, social criticism recognizing the risks and obstacles promoted by social issues and the search for autonomy in political participation. The search for changes in social vulnerability must have a solid foundation with cultural creativity acting directly with social protection and quality education.

In recent years, several studies have been developed on the historical scenario in which Brazilian cultural policy was presented. Emergency concerns that needed political institutional reorganizations were then highlighted (DIAS DA SILVA, 2014). The changes promoted in recent years in the area of culture had as guidelines: the reinsertion of culture on the nation's agenda, the interiorization of initiatives and the pluralization of identity, creating new foundations and municipal secretariats of culture to promote new cultural practices.

With recent educational policy changes and new cultural organizations taken, in order to renew interdisciplinary and intersectoral perceptions, initiatives that sought constant approximations with cultural policies were centralized (DIAS DA SILVA, 2014).

Few were as intense as the approaches and collaborations between the educational and cultural sectors, where the perspective of educating for culture, educating for diversity, educating for difference, educating for heritage conservation or traditional cultures occupied centrality in sociocultural narratives of our time. (DIAS DA SILVA, p. 200, 2014).

Thus, heritage education, aiming at disseminating information, knowledge and learning, shows up as a necessary tool that must be used by public-private incentives, and supported by the whole community, minimizing issues relating to cultural vulnerability.

\section{FINAL CONSIDERATIONS}

From the analysis of the evolution of normative acts, and considering the public policies currently in force, in the different administrative spheres, the evolution of actions to protect and promote cultural heritage is clear.

Throughout the research presented, the easy access to information inherent to preservation policies was observed, mainly at the federal and state level. Regarding the documentation available with regard to municipal public policies, it was possible to access some documets only physically, directly with the responsible municipal people, a fact that ends up limiting the 
community in general in the knowledge of these data, reflecting in the minimization of actions that meet cultural and local development.

Thus, there is a need to enhance greater articulation between governments and different local actors, fostering collaborative and cooperative work, with the purpose of encouraging the creation of cultural, social and educational projects, defined based on normative acts.

\section{AGRADECIMENTOS}

We thank Joana Ribas Bernardes Lima for translating our text.

\section{REFERENCES}

ÁVILA, V. F. Pressupostos para a formação educacional em desenvolvimento local. Interações, Campo Grande, v. 1, n. 1, p. 63-76, 2000.

BRASIL. Decreto n. 3551, de 4 de agosto de 2000. Institui o registro de bens culturais de natureza imaterial. Brasília, DF, 2000.

BRASIL. Constituição da República Federativa do Brasil de 1988. Brasília, DF, 1988. Available at: http:// www.planalto.gov.br/ccivil_03/constituicao/constituicao.htm. Access on: 19 June 2021.

BRASIL. Decreto-Lei n. 25, de 30 de novembro de 1937. Organiza a proteção do patrimônio histórico e artístico nacional. Brasília, DF. 1937. Available at: http://portal.iphan.gov.br/uploads/legislacao/Decreto_ no_25_de_30_de_novembro_de_1937.pdf. Access on: 19 June 2021.

BRASIL. Lei n. 3.924, de 30 de novembro de 1961. Dispõe sobre os monumentos arqueológicos e préhistóricos. Brasília, DF, 1961.

BRAZ, M. G.; OLIVEIRA, O. Territorialidades religiosas e devoção privada em Irati, PR. Interações, Campo Grande, v. 14, n. 1. p. 107-12, 2013.

BUSSO, G. El enfoque de la vulnerabilidad social en el contexto latinoamericano: situación actual, opciones y desafíos para las políticas sociales a inicios del siglo XXI. Santiago: CEPAL, 2001.

CALABRE, L. Políticas culturais no Brasil: dos anos 1930 ao século XXI. Rio de Janeiro: Editora FGV, 2009.

CANÇADO, T. C. L; SOUZA, R.S, CARDOSO, C.B.S. Trabalhando o conceito de vulnerabilidade Social. In: ENCONTRO NACIONAL DE ESTUDOS POPULACIONAIS, 19., 24-28/nov., São Paulo. Anais [...]. São Paulo: ABEP, 2014.

CANDAU, J. Memória e identidade. Tradução de Maria Letícia Ferreira. 1. ed. São Paulo: Contexto, 2012.

CASTRO, M. G.; ABRAMOWAY, M. Juventudes no Brasil: vulnerabilidades negativas e positivas. In: CONGRESSO DA ASSOCIAÇÃO LATINO AMERICANA DE POPULAÇÃO [ALAP], 1., 18-20/set. 2004, Caxambu. Anais [...]. Caxambu: ALAP, 2004.

DIAS DA SILVA, R. M. As políticas culturais brasileiras na contemporaneidade: mudanças institucionais e modelos de agenciamento. Sociedade e Estado, Brasília, v. 29, n. 1, p. 199-224, 2014.

IBGE. Indicadores sociais municipais/Porto Murtinho: uma análise dos resultados do universo do Censo Demográfico 2010. Rio de Janeiro: 2010. (Estudos e pesquisas: informação demográfica e socioeconômica, n. 28). 
INSTITUTO DO PATRIMÔNIO HISTÓRICO E ARTÍSTICO NACIONAL [IPHAN]. Ordinance n. 420, of December 22. Dispõe sobre os procedimentos a serem observados para a concessão de autorização para realização de intervenções em bens edificados tombados e nas respectivas áreas de entorno. Portal do Iphan Brasília, DF, 2010. Available at: http://portal.iphan.gov.br/uploads/legislacao/Portaria_n_420_de_22_ de_dezembro_de_2010.pdf. Access on: 19 June 2021.

LIMA, M. M. E. R. Ciclos econômicos e produção arquitetônica em Porto Murtinho. Campo Grande: Fundação de Cultura de Mato Grosso do Sul, 2013.

MATO GROSSO DO SUL (Estado). Lei n. 5.035, de 31 de julho de 2017. Altera a Lei no 3.522, de 30 de maio de 2008, que dispõe sobre a proteção do patrimônio Histórico, Artístico e Cultural de Mato Grosso do Sul. Campo Grande, MS, 2017. Available at: https://www.spdo.ms.gov.br/diariodoe/Index/Download/ D09462_01_08_2017. Access on: 19 June 2021.

MATO GROSSO DO SUL (Estado). Lei n. 3.522, de 30 maio de 2008. Dispõe sobre a proteção do patrimônio histórico, artístico e cultural de Mato Grosso do Sul. Campo Grande, MS, 2008a. Available at: http://www. fundacaodecultura.ms.gov.br/wp-content/uploads/2017/01/Lei-3.522_2008.pdf. Access on: 19 June 2021.

MATO GROSSO DO SUL (Estado). Decreto n. 12.686, de 30 de dezembro de 2008. Regulamenta a Lei no 3.522, de 30 de maio de 2008, que "Dispõe sobre a proteção do Patrimônio Histórico, Artístico e Cultural de Mato Grosso do Sul", e dá outras providências. Campo Grande, MS, 2008b. Available at: http://www. fundacaodecultura.ms.gov.br/wp-content/uploads/2017/01/Normas-de-tombamento-1.pdf. Access on: 19 June 2021.

PORTA, P. Políticas de preservação do patrimônio cultural no Brasil: diretrizes, linhas de ação e resultados. Brasília, DF: IPHAN, 2012.

PORTO MURTINHO (Cidade). Lei Municipal n. 1461, de 17 de fevereiro de 2011. Reformula o conselho municipal de cultura no município de Porto Murtinho. Porto Murtinho, MS, 2011 .

PORTO MURTINHO (Cidade). Lei Municipal n. 1462, de 17 de fevereiro de 2011. Cria o fundo municipal de incentivo à cultura no município de Porto Murtinho. Porto Murtinho, MS, 2011b.

PORTO MURTINHO (Cidade). Lei Municipal n. 1403, de 23 de abril de 2009. Dispõe sobre a proteção do patrimônio cultural do município de Porto Murtinho. Porto Murtinho, MS, 2009.

SANTOS, M. A Natureza do espaço. 4. ed. São Paulo: Editora da Universidade de São Paulo, 2006.

SCHUMANN, L. R. M. A. A multidimensionalidade da construção teórica da vulnerabilidade: análise históricoconceitual e uma proposta de índice sintético. 2014. 165 f. Dissertação (Mestrado em Desenvolvimento, Sociedade e Cooperação Internacional) - Universidade de Brasília, Brasília, DF, 2014.

SILVA, J. A. Direito urbanístico brasileiro. 6. ed. São Paulo: Malheiros editores, 2010.

UNES, W.; CAVALCANTE, S. Fênix: restauro da Igreja Matriz de Pirenópolis. Goiânia: Instituto Casa Brasil de Cultura, 2008.

VIGNOLI, J. R. Vulnerabilidad Demográfica en América Latina: qué hay de nuevo? In: SEMINARIO VULNERABILIDAD, Santiago de Chile, 2001. Santiago de Chile: CEPAL, 2001. Available at: http://www. nepo.unicamp.br/publicacoes/livros/vulnerabilidade/arquuivos/arquuivos/vulnerab_cap_4_pgs_95-142. pdf. Access on: 19 June 2021.

VILLELA, A. T. C. Técnicas retrospectivas, restauração e patrimônio histórico. Londrina: Editora e Distribuidora Educacional S.A, 2017. Available at: http://cm-kls- content.s3.amazonaws.com/201702/INTERATIVAS_2_0/ 
TECNICAS_RETROSPECTIVAS_RESTAURACAO_E_PATRIMONIO_HISTORICO/U1/LIVRO_UNICO.pdf. AccesS on: 19 June 2021.

\section{Sobre as autoras e o autor:}

Mariana de Barros Casagranda Akamine: Masters student in Local Development at the Dom Bosco Catholic University (UCDB). Specialized in Interior Design at UCDB and in Sustainable Environmental Rehabilitation at the University of Brasilia (UnB). Graduated in Architecture and Urbanism at Anhanguera-Uniderp. E-mail: mariana_casagranda@yahoo.com.br, Orcid: http://orcid.org/0000-0001-9605-1061

Érika Santos Silva: Doctorate student in Local Development through the Context of Territorialities at the Dom Bosco Catholic University (UCDB). Graduated in Visual Arts at the Federal University of Mato Grosso do Sul and in Architecture and Urbanism at Anhanguera-Uniderp. Participates of the research group "Cultural Heritage, Rights and Diversity" of the Nacional Council of Scientific and Technological Development (CNPq). E-mail: erikasantos.arqdeco@gmail.com, Orcid: https://orcid.org/0000-0003-3715-8015

Maria Margareth Ribas Escobar Lima: PhD at the University of Lisbon, in Portugal. Doctorate in Environment and Development at Anhanguera-Uniderp. Master's Degree in Architecture at the Federal University of Rio Grande do Sul (UFRGS). Graduated in Architecture and Urbanism at the Gama Filho University (UGF). Currently works as a full professor at the Federal University of Mato Grosso do Sul. E-mail: margareth18sr@hotmail.com, Orcid: https://orcid.org/0000-0002-4118-4382

Rodrigo Mendes de Souza: Doctorate student in Theory of Art at the University of São Paulo (USP). Master's degree in History of Art at USP. E-mail: rodrigo.mendes@ufms.br, Orcid: https://orcid.org/0000-0001-7169-9670 
